\title{
METHODOLOGICAL PRINCIPLES OF DIACHRONIC STUDY OF LINGUISTIC VARIATION IN THE UKRAINIAN LANGUAGE
}

\author{
Inna Tsaralunga \\ Khmelnytsky National University, Ukraine, \\ tsaralungainna@ukr.net
}

\begin{abstract}
The article analyses the system of methodological principles employed in the comprehensive study of linguistic variation in diachrony. In particular, the author defines the essence of the scientific principle as a means of linguistic study as well as thoroughly describes the system of methodological principles of a diachronic study of any linguistic variations. The described methodological foundations of a diachronic study are substantiated through the prism of Ukrainian written monuments of the late Middle Ages. The paper also outlines the prospects of further theoretical and methodological scientific studies for historical linguistics. The study material comprises more than nine thousand variable language elements, recorded in the texts of business and religious writing of the late Middle Ages. The sources for the study are represented by handwritten and printed monuments of the official style of the Old Ukrainian language and the religious style of the Church Slavonic language of the Ukrainian edition. As a result of the carried out research, it has been defined that the methodology of diachronic study of variable language phenomena is based on the principles of a scientific and objective approach to the variation of the literary language in historical conditions on the basis of a complex unity of historical, systemic, anthropocentric, and synergetic directions of linguistic studies. The described methodological aspects of the study of linguistic variations can be used in training courses of general linguistics, historical grammar of the Ukrainian language, the history of the Ukrainian literary language and historical dialectology as well as in the following optional courses: "Language Variation in Diachrony", "Principles and Methods of Linguistic Analysis of Linguistic Variation", "Formation of the Ukrainian Language Standards" for students of philological departments.
\end{abstract}

Keywords: language; variant; variation; methodological principle; diachrony; Old Ukrainian language.

\section{Introduction}

Language is the result of numerous intra- and extra-linguistic changes that occur in the process of its development and are reflected in split-level variable elements, resulting in the variation of the language system as a whole. Variation is one of the internal factors of the language changeability, the effect of which is associated with internal and external factors of the language development, realised through the creation, selection, operation of variants of linguistic units, that is, in the process of variation.

The systemic study of variable language units in the context of a certain territorial-linguistic formation broadens the empirical base of historical dialectology, deepens the guidelines of historical grammar, in particular, of the Ukrainian language and other Slavic languages, discovers new approaches to the territorial division of a certain language during a certain period of its development.

Linguistic deviations, linguistic confusions, and linguistic doublets are fragmentarily considered in the works of Ukrainian linguists. Ohiienko (1930) discovered linguistic confusions on the phonetic and morphological levels in the text of the Krekhiv Apostle of the XVI century, for example, the variative manifestations of the former $* \check{e}$, double forms reflecting the change $e>o$, palatal and hard $p$, doublet caseforms of nouns, variative forms of adjectives, parallel personal endings in the verbs of the first person plural, etc. (pp. 239-279, 317-360). While studying the language of the Transcarpathian documents of the second half of the XVI and early XVII centuries, Pankevych (1958) made conclusions grounded on his observations of the language of the Niagov Gospel Exhortations, the Uglian Gospel, the Torun and Sokyrnytskyi collections, and other written sources from this area (pp.171-181). According to the researcher, the scribes of the mentioned records applied the principles that were different from the norms of the Ukrainian literary language adopted in the western Ukrainian territories, so the old texts reflect the whole phonetic and grammatical structure of the Maramoros dialect of that time, in which, along with the Old Church Slavonic language forms, numerous dialectisms are found. In his turn, Nimchuk (1981), describing the language of the acts of Volyn and Naddnieper Ukraine of the XVII century, discovered in general the north-Ukrainian dialectal sound characteristics of the language of the records, which are evident in deviations from the old Ukrainian etymological spelling, as well as recorded archaic and innovative elements in the morphology of the acts (pp. 14-20).

It should also be mentioned that a number of aspects of the Ukrainian language development are covered in the studies of foreign linguists. Thus, Kuraszkiewicz (1934), a Polish researcher, while investigating the language of the Galician-Volhynian Chronicles of the XIV - XV centuries, substantiated the influence of the linguistic tradition, dialects, and linguistic analogy on the appearance of doublet forms of different language levels. Stang (1935), a Norwegian linguist, in his research study on the formal language of

Tsaralunga, I. (2019). Methodological principles of diachronic study of linguistic variation in the Ukrainian language. Advanced Education, 13, 26-35. DOI: 10.20535/2410-8286.154597 
the Grand Duchy of Lithuania, consistently distinguished among the characteristic phonetic features the phenomenon of vowel deviations in the texts of documents of the XIV - XV centuries, and found out the reasons for these changes (pp. 14-33). Andersen (1969) analysed Ukrainian prefixes in diachrony (pp. 809, 824-825). The researcher pointed out morphological changes in the grammatical structure of the word, taking into account the pre-Ukrainian, early Ukrainian, and modern Ukrainian forms, and clarified the causes and mechanisms of the appearance of variative linguistic units.

In our previous work, we analysed the system of linguistic methods for studying the variation phenomenon on the material of the written records of the late Middle Ages (Tsaralunga, 2018), but solving the problems of standardisation of the language as a system at different stages of functioning and solving the problem of streamlining its lexical, phonetic, and grammatical structure require further improvement of the methodological foundations of such research.

The methods and principles of diachronic analysis in terms of content and purpose are somewhat different from the methodology of synchronic linguistics, although, obviously, they are not applied separately from it. As Tarlanov (1995) thinks, methods of synchrony, having been developed even before the birth of diachronic linguistics, in canonical form served for the sole purpose - verifying and prescribing, since the methods of diachrony were oriented primarily at explaining the language facts, the search for answers to the questions: is the present state of a language eternal, what is the life of a language (languages) in time and space? (p. 115).

The problem of the development of the Ukrainian language is reflected in numerous scientific articles and manuscripts; it has been effectively worked out in Ukrainian historical linguistics. However, from this perspective Pivtorak (2015) remarks that the vast majority of scientists "...completely sidestep the theoretical foundations and methodological viewpoints, on the basis of which they build the research" (p. 5). The linguist emphasises various aspects of the theory and methodology of scientific studies on the ethnogenesis of different peoples and the glottogenesis of related languages, the importance of creating a comprehensive universal theory that could be used in the study of history of any particular language or related languages, taking into account the specifics of their formation and development (Pivtorak, 2015, p. 6). Therefore, it is important today to develop a methodology for the analysis of written monuments of various genres and styles for the systematic study of variable phonetic, morphological and other elements of literary and written language, for finding out the causes of linguistic variances as well as defining the role of dialects and foreign language influences in the occurrence of linguistic variation.

The aim of the study is to describe the system of methodological principles of the comprehensive study of linguistic variations in diachrony as the means of providing a system of procedures for analysing the phenomenon of language parallelism using the data from Ukrainian written monuments.

This aim is achieved by performing a set of the following tasks: to define the essence of the scientific principle as a means of linguistic research; to characterise the system of methodological principles of diachronic study of linguistic variation; to reflect the described methodological principles through the prism of the Ukrainian literary monuments of the late Middle Ages; to outline the prospects of theoretical and methodological scientific studies for historical linguistics.

\section{Methods and data collection}

Different research methods have been applied to the study of linguistic variation of the late Middle Ages period. During the data collection, we used the method of a formal analysis, which helped group the language elements of different levels according to their definite features. The structural method is employed to studying the structure of the language and systematisation of its units, the comparative method is used to define the variation of continuative forms of ancient sounds and parallel word forms. The process of the emergence of variants of the Ukrainian literary language has been substantiated with the help of a comparative-historical method; the interpretation of the revealed language phenomena is carried out with the use of a descriptive method. The linguo-geographical method is used at studying the territorial spread of language phenomena. The dynamics of variable elements is analysed by mapping and applying the method of quantitative calculations.

The data under study comprises over 9,000 variable language elements recorded in the texts of business and religious writing of the late Middle Ages. The source of the material under study is represented by the handwritten and printed monuments of the official style of the Old Ukrainian language and the religious style of the Church Slavonic language of the Ukrainian edition. The linguistic analysis also involves the materials of the published historical dictionaries: the Dictionary of the Old Ukrainian language of the XIV - XV centuries, the Dictionary of the Ukrainian language of the XVI - the first half of the XVII 
centuries, as well as dialectal and etymological dictionaries. The Atlas of the Ukrainian language is used to compare the evidence of written monuments and the facts of modern linguogeography.

\section{Results and Discussion}

The multidimensionality of language as the object of scientific studies predetermines the diverse nature of methodological approaches. Thus, according to Selivanova (2008), the study of the laws of language development in diachrony, the elucidation of the evolutionary character of language changes in the context of the problem of linguistic variation can take place in terms of a certain scientific paradigm, which is recognised as a pattern of knowledge and actions in a given period in the society in question, which give a model for problems statement and their solution in the scientific community (p. 15). Analysing the history of linguistics, the researcher distinguishes the functioning of such main scientific paradigms:

- genetic (comparative-historical, evolutionary), which gained special importance in linguistics of the $\mathrm{XX}$ century, was guided by the principles of historicism, diachronic language consideration;

- taxonomic (systemic-structural), which dominated in the first half of the XX century and was based on the principles of synchronicity of linguistic description, ontological dualism of invariants and variants of language units, language systemacity;

- pragmatic (communicative-functional), the formation of which took place in the second half of the XX century and led to the analysis of the human factor in the language, envisaged the consideration of language as an instrument of human success achievement, etc.;

- cognitive (or cognitive-discursive), aimed at explaining the constant correlations and connections between language, language products, on the one hand, and the structures of knowledge, thinking and consciousness operations, on the other hand (Selivanova, 2009, p. 210-211).

In the context of each of them, the most important methodological tool, the basis of cognition and the theoretical and methodological basis is the scientific principle. According to Hlushchenko (2010), the global statements with a wide range of actions of strategic importance act as principles (p. 42). A principle as a means of scientific study is decisive in its initial, intermediate and final stages. The body of principles of the scientific study of linguistic phenomena is of paramount importance for diachronic linguistics.

\section{The principle of objectivity of the study}

The methodology of the complex analysis of the phenomenon of language parallelism in the historical aspect embraces a number of principles. The principle of objectivity is manifested in the comprehensive consideration of the factors that give rise to one or another phenomenon in finding of adequate research methods. For objective conclusions on the spread of one or another territorial-linguistic formation in the past, the study should be comprehensive, simultaneously taking into account a number of factors.

Diachronic complexes of variable language elements appear in focus of a certain epoch as a result of cause-effect relationships of socio-political events, spiritual and educational processes, linguistic and ethnic consciousness, etc. The development of the Ukrainian language of the XIV - XV centuries took place in the conflicting historical conditions that Farion (2015) rightly calls "....antagonistic and paradoxical: the constant development and opposition, retreat and establishment against the backdrop of threatening political circumstances, because of which Rus turned out to be a part of different states" (p. 229), hence the differences in the midst of the language itself between its northern and south-western variants were deepened.

From the standpoint of the scientific and objective approach, the diachronic study of variation should be made taking into account the external and inter-language factors of the development of the Ukrainian language during the late Middle Ages period. The written speech on the Ukrainian lands of the XIV - XV centuries was the privilege of a certain part of the society, primarily elites, associated with political power, regulation of life, the spread of certain ideological systems, etc. The language historians emphasise the fact that the traditional writing, the Old Bulgarian vocabulary, the bookish-church range of concepts and ways of expressing opinions largely fence off the researchers to the living language environment of the old Ukrainian language of that time, therefore, for various reasons the oral speech does not find an adequate reflection in writing (Moisiienko, 2016, p. 11). Such situation became more complicated by adapting of clerks to the current graphical system, which was not always able to reproduce live folk speech. Therefore, the preconceptual study of the language historian partly involves the diligent picking up of errors and omissions, which were made by the clerks at that time under the active folk-speaking influence, which is stipulated by the method of formal analysis of the texts of the preserved written monuments of the specified period.

For the objectivity of the study, it is expedient to process the actual material of as many preserved written monuments as possible in the complex with the dialectical sources available for today, since giving preference to either of the facts of the monuments or linguogeography, obviously, will lead the researcher to false conclusions. According to the assumptions of Buzuk (1931) as for the historical study of language, 
“...when we have at our disposal the required number of monuments from different countries and different time, we, by comparing their evidence with data of dialects, could find out about where and when a certain phenomenon was born, and then over what centuries and in which directions it was developed" (p. 113). However, the irregular geographical and temporal distribution of ancient documents, their late copies and the influence of traditional orthography complicate the solution of the topical problems of Ukrainian linguistics. More attention should be paid to the parallel writing in the texts of documents that can give an idea of their authors' speech, about the folk-speaking specific character in different regions, about the peculiar features of Ukrainian glottogenesis. Just "...in the slips of pen and variant spellings that are often encountered in the most ancient written monuments of the second half of the XI century with the consistent growth in subsequent periods", the researchers advise to seek the display of the corresponding dialect features, processes and phenomena, "...tens and hundreds of cases of reflection of language features that are characteristic for the living Ukrainian language" (Pivtorak, 2015, p.9). For example, we have implemented and depicted this approach in the table "The phonetic variation in the monuments of the official-business style of the XIV - XV centuries" (see Table 1).

Table 1. "The phonetic variation in the monuments of the official-business style of the XIV - XV centuries"

\begin{tabular}{|c|c|c|c|c|c|c|}
\hline \multirow{2}{*}{$\begin{array}{c}\text { Phonetic } \\
\text { phenomenon and } \\
\text { its preliterate } \\
\text { (proto-Slavic) } \\
\text { manifestation }\end{array}$} & \multirow{2}{*}{$\begin{array}{c}\text { Inherited } \\
\text { ancient forms }\end{array}$} & \multirow{2}{*}{$\begin{array}{l}\text { Features, } \\
\text { found in the } \\
\text { northern } \\
\text { monuments, } \\
\text { typical of } \\
\text { modern } \\
\text { northern } \\
\text { dialects }\end{array}$} & \multirow{2}{*}{$\begin{array}{l}\text { Features, found in the } \\
\text { southwest monuments, } \\
\text { typical of modern } \\
\text { southwest dialects }\end{array}$} & \multicolumn{2}{|c|}{ Borrowings from other languages } & \multirow{2}{*}{$\begin{array}{c}\text { Differential } \\
\text { features of } \\
\text { modern } \\
\text { Ukrainian } \\
\text { language }\end{array}$} \\
\hline & & & & $\begin{array}{l}\text { South Slavic } \\
\text { (Middle } \\
\text { Bulgarian) }\end{array}$ & $\begin{array}{l}\text { West Slavic } \\
\text { (Polish) }\end{array}$ & \\
\hline 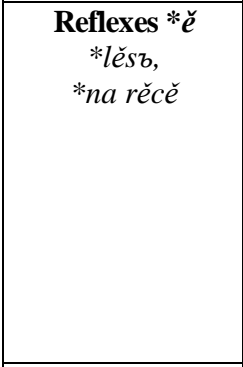 & 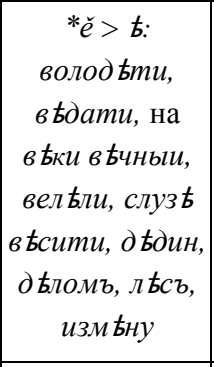 & $\begin{array}{c}\text { *е̌ >е: } \\
\text { воєводє, } \\
\text { в городє, } \\
\text { завешона, } \\
\text { замєнити, } \\
\text { мещзаны, } \\
\text { повыменяль, } \\
\text { полеский, на } \\
\text { рєиє, } \\
\text { сєножатми }\end{array}$ & $\begin{array}{c}\text { *е̌ > } i: \text { оу Било }(м) \\
\text { Городь, дитемъ, } \\
\text { роздиляючися, свидичи, } \\
\text { вирную, липшє, } \\
\text { у пасици, прыцхаль }, \\
\text { соби }\end{array}$ & $\begin{array}{c}\text { Manifestations } \\
\text { и: вирному, } \\
\text { вси(м), в блили, } \\
\text { диль, } \\
\text { крипос }(m), \\
\text { ли }(m), \\
\text { ис симъ, тимъ }\end{array}$ & & $\begin{array}{c}\text { білий, віра, } \\
\text { діло, } \\
\text { завімений, } \\
\text { замінити, } \\
\text { ліпше, міський, } \\
\text { на пасіиці, } \\
\text { поліський, на } \\
\text { ріиі, } \\
\text { сіножать, собі }\end{array}$ \\
\hline $\begin{array}{c}\text { Reflexes *'a } \mathbf{\text { Ta }}{ }^{*} e \\
\text { *devętb, } \\
\text { *měsęcb }\end{array}$ & \begin{tabular}{|c|} 
*'а, *е> > $/ z / я:$ \\
всикому, \\
вступоватиси, \\
девит (b), \\
книзь, мбсяия, \\
пьнизи, \\
свzтого, \\
станься, \\
тисячей
\end{tabular} & $\begin{array}{c}\text { *'a, *e> }^{*} \text { : } \\
\text { впаметанья, } \\
\text { дєвєтдєсать } \\
\text { десе }(\text { m), виме, } \\
\text { месеча, } \\
\text { пьнезей, } \\
\text { розвезати, } \\
\text { светое, } \\
\text { склоняючисе, } \\
\text { тисеча, } \\
\text { хотечи }\end{array}$ & & $\begin{array}{c}\text { Manifestations } \\
\text { Ђ: дєс бтину, } \\
\text { зав бзск(y), } \\
\text { кн бгиню, } \\
\text { моунтт бнскыи, } \\
\text { прис бгнути, } \\
\text { с ппокусить, } \\
\text { оуз бти, чєл бди }\end{array}$ & & $\begin{array}{c}\text { дев'ять, ім'я, } \\
\text { княгиня, } \\
\text { місячь, } \\
\text { пам'ять, } \\
\text { розв'язати, } \\
\text { святиии, } \\
\text { спокуситися, } \\
\text { тисяча, } \\
\text { хотячи }\end{array}$ \\
\hline $\begin{array}{c}\text { Change of } \\
\text { etymological } * \overline{\boldsymbol{e}} \\
\text { and } * \overline{\boldsymbol{o}} \\
* \text { koliko, } \\
* \text { tetbka }\end{array}$ & $\begin{array}{l}\text { болшєє, } \\
\text { пановъ, } \\
\text { тетъка, } \\
\text { шесть }\end{array}$ & & $\begin{array}{c}\text { о, е> у, ю: бу(л)шєє, } \\
\text { годувлю, добровоульно, } \\
\text { Журжь, ку (л)косъ, } \\
\text { панҮв(ь), попоу (д), } \\
\text { прҮзвищемъ, торгувли, } \\
\text { Федуть; грошювъ, } \\
\text { королювства, } \\
\text { по нюмъ, своюй, } \\
\text { слюбуюмъ, тютка, } \\
\text { оу ту (м) }\end{array}$ & & & $\begin{array}{c}\text { більший, } \\
\text { годівлю, } \\
\text { добровільно, } \\
\text { кількість, } \\
\text { королівство, } \\
\text { умоїм, панів, } \\
\text { попід, потім, } \\
\text { прізвище, } \\
\text { своїи, у тім, } \\
\text { тітка, иість }\end{array}$ \\
\hline 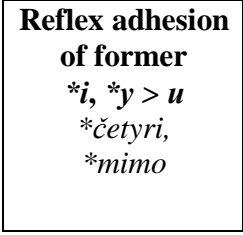 & $\begin{array}{c}\text { дали, мимо; } \\
\text { вышє, сыномь }\end{array}$ & 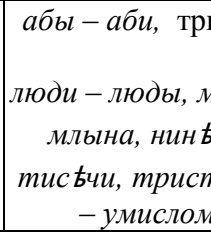 & 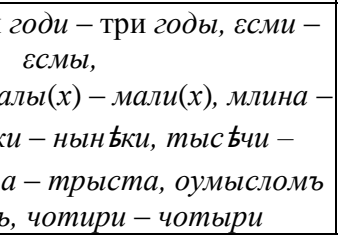 & & & $\begin{array}{c}\text { аби, люди, } \\
\text { малий, млин, } \\
\text { нині, тисяча, } \\
\text { триста, } \\
\text { чотири }\end{array}$ \\
\hline
\end{tabular}




\begin{tabular}{|c|c|c|c|c|c|c|}
\hline $\begin{array}{l}\text { Distribution of } \\
\text { initial *je }>\boldsymbol{o} \\
\quad * \text { edinb } \\
\quad * \text { ezero }\end{array}$ & 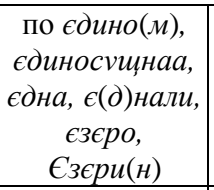 & \multicolumn{2}{|c|}{$\begin{array}{c}\text { јдно, по одномъ, јдноу, ожє, озеро, } \\
\text { јзерие, Јзєринь, Оленка, Олеф ьрько, } \\
\text { Осташко, Јхр Бмъ }\end{array}$} & & & $\begin{array}{c}\text { Оленка, один, } \\
\text { озеро, } \\
\text { Озеряни, } \\
\text { Осташко, } \\
\text { Охрім } \\
\end{array}$ \\
\hline $\begin{array}{l}\text { Change of } e \text { after } \\
\text { fricatives } \\
*_{c ̌ c l o,} \\
*_{z ̌ e n a}\end{array}$ & 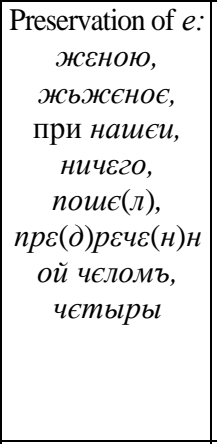 & $\begin{array}{c}\text { e> о: божого, } \\
\text { бочокъ, будучого, } \\
\text { вжо, грошовою, } \\
\text { тамъ жо, жонъка, } \\
\text { Золочов, нашому, } \\
\text { ничого, с блищо, } \\
\text { чоловєковъ, } \\
\text { Чорный, } \\
\text { Чорторыиского, } \\
\text { чотыриста, } \\
\text { лєто шосто }\end{array}$ & & & $\begin{array}{c}e>\text { in } \\
\text { раrticiрles: } \\
\text { завешона, } \\
\text { непорушоно, } \\
\text { ображоному, } \\
\text { позычоныхъ, } \\
\text { положона, } \\
\text { посв бтчонъ, } \\
\text { почонъ, } \\
\text { преречоный, } \\
\text { принужоный, } \\
\text { уложона }\end{array}$ & \begin{tabular}{|c|} 
божсого, \\
громовий, \\
нічого, \\
нашому, пішов, \\
чоловік, \\
чорний, \\
чотириста, \\
шовк, \\
шостий \\
\end{tabular} \\
\hline $\begin{array}{l}\text { Reflexes *tort, } \\
\text { *tolt, *tert, *telt } \\
\quad * \text { dervo, } \\
\quad *_{\text {zolto }}\end{array}$ & $\begin{array}{l}\text { боронити, } \\
\text { волод ьти, } \\
\text { ворота, } \\
\text { черезъ }\end{array}$ & \multicolumn{2}{|c|}{$\begin{array}{c}\text { Бєлогоро (д)а, Бєрєговъ, Берестью, } \\
\text { з болоты, Володиславь, Воронєиь, на } \\
\text { городє, } \\
\text { золота, в колодє, молодому, в середу, } \\
\text { стерегуть, Чєрєватого }\end{array}$} & $\begin{array}{c}\text { блато, на } \\
\text { брьзъ, } \\
\text { Бьлограда, } \\
\text { Владимир, } \\
\text { Владиславу, } \\
\text { Вра(н)ча(н), } \\
\text { во граде, } \\
\text { здравїє, } \\
\text { златьл( }), \\
\text { краль, } \\
\text { на планину, } \\
\text { исъ } \\
\text { сла(д)ницююо }\end{array}$ & 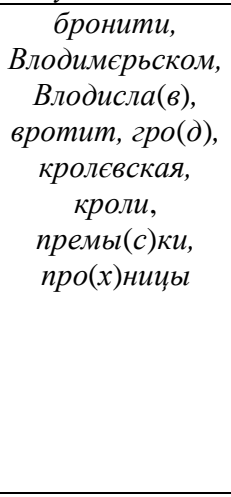 & $\begin{array}{c}\text { берег, болото, } \\
\text { боронити, } \\
\text { Володимир, } \\
\text { город, } \\
\text { здоров'я, } \\
\text { золотий, } \\
\text { колода, } \\
\text { молодий, } \\
\text { середа, } \\
\text { солодкий, } \\
\text { стерегти, } \\
\text { черево }\end{array}$ \\
\hline $\begin{array}{l}\text { Non- } \\
\text { palatalisation of } \\
\text { fricative } \\
\text { consonants } \\
*_{\text {tysetja }} \\
*_{z \check{z} e t i}\end{array}$ & \begin{tabular}{|c|} 
держит (b), \\
нашю, св бдчю, \\
тисячя, \\
щииткове
\end{tabular} & \multicolumn{2}{|c|}{$\begin{array}{l}\text { в Галичу, держати, Дробыша, Журжь, } \\
\text { ливовчанє, нашу, полочаны, јборочати, } \\
\text { пєча }(\text { m), праоунучатомъ, Ста (н)чоу (л), } \\
\text { сьножатьми, тисяча, урочища }\end{array}$} & & & $\begin{array}{c}\text { Галич, } \\
\text { держати, } \\
\text { нашу, печать, } \\
\text { правнуча, } \\
\text { сіножать, } \\
\text { тисяча, } \\
\text { урочище } \\
\end{array}$ \\
\hline $\begin{array}{c}\text { Palatalisation/ } \\
\text { non-palatalisation } \\
\text { of } \boldsymbol{u} \\
\text { *měsęcb, } \\
\text { *ovbca }\end{array}$ & \begin{tabular}{|c|} 
двадичить, \\
м бсиичи, \\
j(m)ции, \\
трынадиятог \\
o
\end{tabular} & 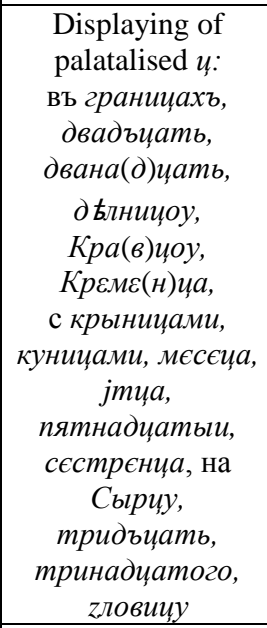 & 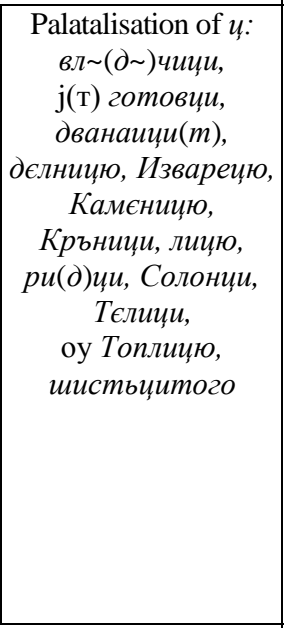 & & & 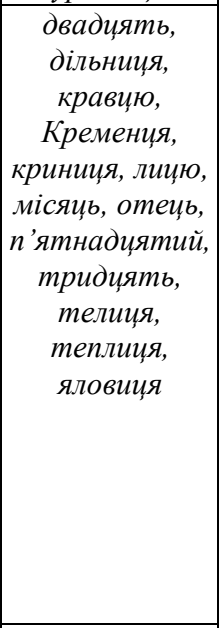 \\
\hline $\begin{array}{l}\text { Assimilation of } \\
\text { sound } j \\
\text { *podanbje, } \\
*_{s^{\wedge} d b j a}\end{array}$ & $\begin{array}{l}\text { Preservation of } j: \\
\text { братїами, } \\
\text { взольєть, } \\
\text { Ильи, начиньє, } \\
\text { у Подольи, } \\
\text { судьz, успєнїє }\end{array}$ & \multicolumn{2}{|c|}{$\begin{array}{c}\text { благословеня, нароженя, јбличе, } \\
\text { отправованя, } \\
\text { за пєча }(m) ю, \text { пода }(\mu) u, c y(\partial) z, \\
\text { чолоби }(m) z\end{array}$} & & & \begin{tabular}{|c|} 
браття, Ілля, \\
ллється, \\
народження, \\
обличчя, \\
печаттю, \\
Поділля, \\
подання, суддя \\
\end{tabular} \\
\hline $\begin{array}{c}\text { Simplification of } \\
\text { sounds in groups } \\
\text { of consonants } \\
\quad{ }^{* c ̌ s s t b n b} \\
\text { *městbce }\end{array}$ & \begin{tabular}{|} 
волостка, \\
книзъства, \\
м бстьиє \\
м бстьчиньы, \\
наместникомъ, \\
честныии
\end{tabular} & \multicolumn{2}{|c|}{$\begin{array}{c}\text { волоска, князтва, кожъды (u), на мисиь } \\
\text { м }, ~ \\
\text { счаслиномъ, намєснику, сємоє льто, чесное }\end{array}$} & власнымм & & \begin{tabular}{|c|} 
власний, \\
кожний, \\
місие, \\
намісник, \\
сьоме, щуасливо
\end{tabular} \\
\hline
\end{tabular}




\begin{tabular}{|c|c|c|c|c|}
\hline $\begin{array}{l}\text { Reflexivity of } \\
* \boldsymbol{d j} \\
*(j) e ̌ z d j^{\wedge}, *^{*} \text { medjā }\end{array}$ & & \begin{tabular}{|c|} 
*dj > ж: Медвижи, межи, нароженя, \\
јсужиємъ, преже, принужєни, \\
прирожоний, рожєство, с твержали, \\
оутверженї \\
*zdj > ждж (жди): \\
јбъвжъдчати, приє (ж)джали \\
приєждчали \\
\end{tabular} & 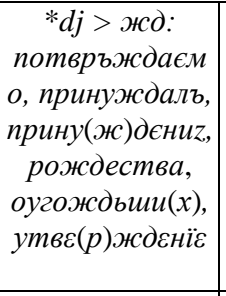 & $\begin{array}{c}\text { догоджати, } \\
\text { межа, } \\
\text { народження, } \\
\text { об'їжджати, } \\
\text { приїжджати, } \\
\text { природжений, } \\
\text { утверджувати }\end{array}$ \\
\hline $\begin{array}{l}\text { Displaying of } \\
\text { the pharyngeal } \\
\text { sound } h\end{array}$ & $\begin{array}{c}\text { голдовалис, } \\
\text { гроши, могилу, } \\
\text { оулєгчили }\end{array}$ & 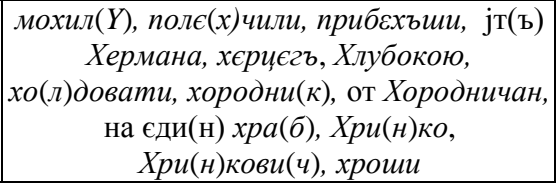 & & $\begin{array}{l}\text { глубока, город, } \\
\text { граб, Гринь, } \\
\text { гроші, могила, } \\
\text { полегшити, } \\
\text { прибігши } \\
\end{array}$ \\
\hline
\end{tabular}

According to the table, in the field of phonetics of Ukrainian records of the XIV - XV centuries, linguistic variation was extremely widespread, both in the system of vocalism and in the system of consonantism. In particular, linguistic variation was typical of the following phenomena: the reflection of the old $* \check{e}$, continuation of the former $*_{e}$ and $*^{\prime} a$, the change of etymological $\overline{\mathrm{e}}$ and $\bar{o}$, adhesion of $* i, *^{*}>u$, distribution of initial $* j e>o$, transition of $e>o$ after sibilants, reflection of such combinations as *tort, *tolt, *tert, *telt, hardening of sibilant consonants, hardening/softening of $u(t s)$, assimilation of the consonant $j$, simplification of sounds in groups of consonants, the change of $* d j$, etc. Using the complex analysis of language parallelism, we have summarised and systematised the phonetic features characteristic of traditional writing, linguistic manifestations that have become differentiating for modern Ukrainian literary language, examples of Ukrainian dialectal speech.

The principle of historicism belongs to the fundamental principles of comparative-historical linguistics. It provides an understanding of a language as a phenomenon that has been historically evolving since the early stages of its formation till the last stages or prospects for its further development (Melnychuk, 2000, p. 311). The historical principle is, of course, relevant to the historical-genetic, typological, areal linguistic studies, including the old Ukrainian literary and written language. In our study, the principle of historicism is realised in the reconstruction of ancient forms of different language levels, comparison of language elements inherited from the previous periods of development, and the newer formations, found in the variable spellings in the official-business and religious texts of the late Middle Ages, in coverage of the influence of other linguistic systems on the Ukrainian writing usage of that time, in determination of historical laws for the development of related languages from the protolanguage (Tsaralunga, 2011; Tsaralunga, 2014; Tsaralunga, 2016).

\section{The principle of systemacity}

The structuralistic scientific paradigm is aimed at studying the language as an ordered system, the hierarchy of language levels. According to the principle of systemacity a language must be studied in its entire essential links with other phenomena of social activity, with the nature and structure of society as a whole, taking into account inter-language interactions, the complex internal interconnection of different language structural levels and elements (Melnychuk, 2000, p. 311). The principle of systemacity in our diachronic study is realised in the context of the structural method: applied to study of the phonetic and morphological variation of the old Ukrainian literary and written language, it has enabled to analyse its sound, grammatical disorder, to find out the peculiar features of the synthesis of language elements, which are heterogeneous at all structural levels, to determine the specifics of the formation of differential features of the Ukrainian language at the phonetic and morphological levels by the features found in the monuments studied.

Rushkovskyi (2014) suggests carrying out a systematic division of variable language elements according to the following criteria: language standardisation (normative and non-normative variants), language levels (orthographic, grammar, lexical, etc.), omnitude of use (systemic and idiolectal), frequency of use (frequent and rare), the chronological criterion (old and new forms), the geographical criterion (regional and general Polish forms), the range of occurrence (professions, etc.), the stylistic criterion (neutral and stylistically marked, for example, expressive, bookish, etc.) (p. 54-59). Hence, in the context of the systematic approach, we have used the method of formal analysis, on the basis of which the language elements of different levels are grouped by specific features, the comparative method is applied to determine the variation of continuative forms of ancient sounds, the parallel word forms. In particular, the system of morphological variants is included in the tables: "The morphological variation in the monuments of officialbusiness styles of the XIV - XV centuries", "The morphological variation in the style of religious monuments of XIV - XV centuries" (Tsaralunga, 2017, p. 432-448). 
The principle of anthropocentrism helps understand the anthropocentric nature of language phenomena and processes, represents the tendency to study the language in close connection with a person, his/her consciousness, thinking, spiritual and practical activity (Kubrjakova, 1995, p. 240). In particular, the anthropic projection of language receives a peculiar tone in the field of dialectology, where special attention is paid to an individual, his/her characteristics, associated with the peculiar features of individual perception of the world, reflection of the worldview in speech, the formation of the dialectal picture of the world as a whole.

Holubovska (2013) insists that the anthropological nomination is the most appropriate name of the modern paradigm of linguistic knowledge: in the sphere of penchant for a person of modern objects of scientific study not only cognitive linguistics is being developed, but also cultural linguistics, lingual conceptology, pragmalinguistics, communicative acts theory, discourse study, etc. (p. 71). So, from the point of view of the study of language variants in diachrony, the problem of language personality is being updated. Many of the written monuments that have come to nowadays indicate about the origin of the clerk, who involuntarily guided by the living folk speech, as well as the level of his education, the knowledge of book writing dogmas, traditions of the document management of that time. It is "language variances", "errors" of local clerks, alternatives, double and parallel language elements that reflect the phonetic and grammatical structure of subdialects, dialects of that time, the struggle of archaic and innovative trends, foreign-language influences.

\section{The principle of dynamism}

Language is a dynamic system that changes under the influence of social processes, responds to the linguistic consciousness of its bearers. The principle of dynamism in linguistics is realised in the study of the peculiar features of the formation and standardisation of norms of the literary language, which are dynamic, varying in their character. According to the researchers' observations the standards do not form monotonous sets of features inherent in the functioning of the units representing the corresponding language levels; therefore, the variation of the standards, the distinction between their central (nuclear) and peripheral manifestations is typical of the literary language (Hryshchenko, 2002, p. 10-11). The changeability of the standards is determined by the internal tension between emerging and disappearing, productive and unproductive, central and peripheral phenomena.

For the analysis of the dynamics of the language elements variation it is appropriate to use mapping, in

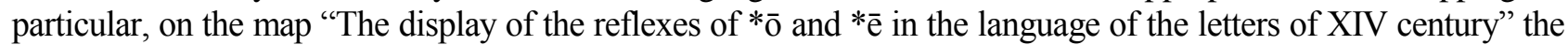
nuclear and peripheral zones of different kinds of continuation of ancient sounds have been traced (see Map 1). The areas of variable elements are also found on other schematic maps of the spread of language phenomena based on the material of the written monuments of the late Middle Ages (Tsaralunga, 2017, p. 392-417).

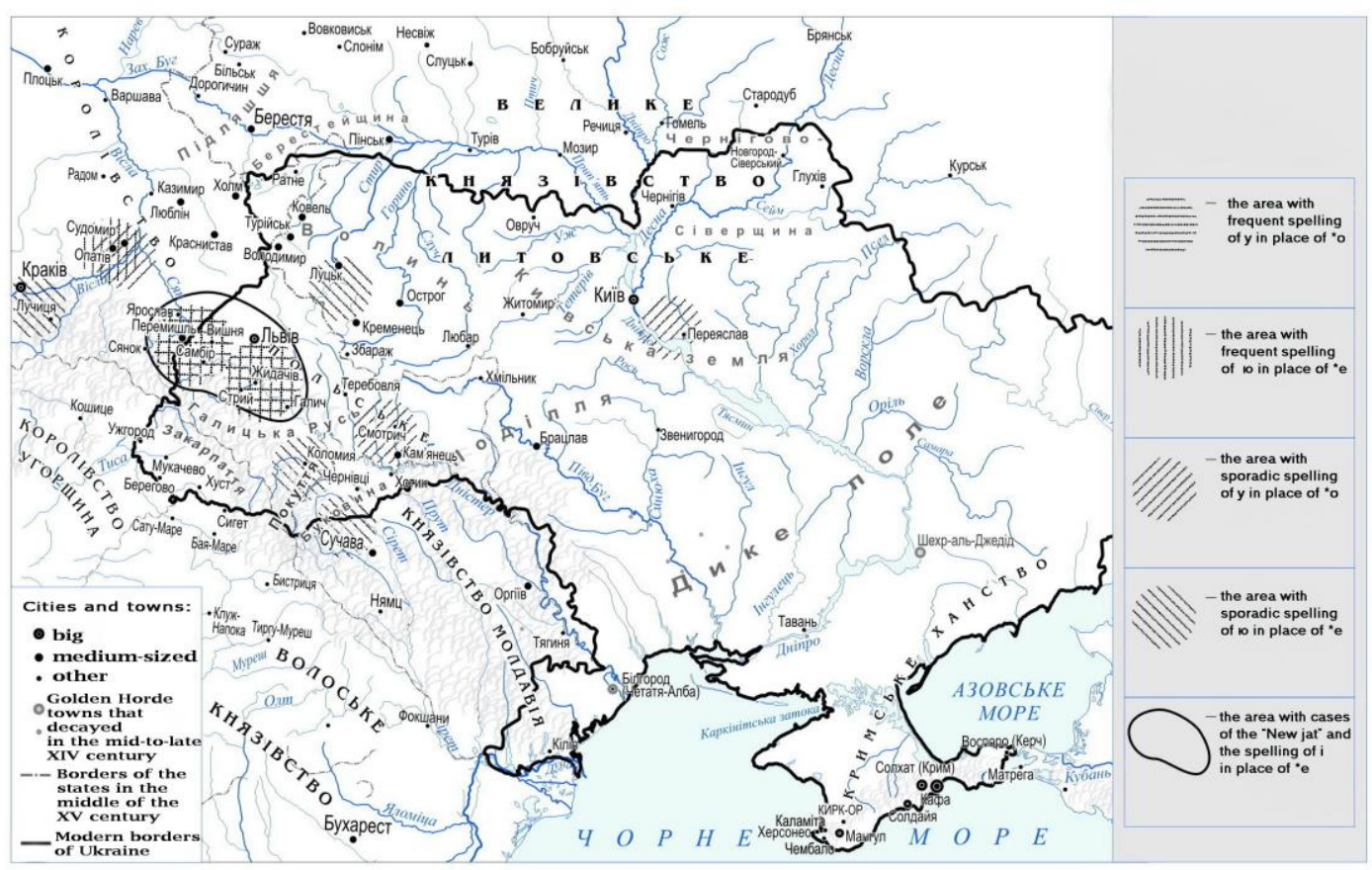

Map 1. The display of the reflexes of $*_{\overline{0}}$ and $* \bar{e}$ in the language of the letters of XIV century 
The study of variable language elements in terms of dynamics makes it possible to detect the processes of decay of old and the formation of new features in its subsystems. The linguists accentuate on the study of "just those processes of development, seeking to balance and symmetry in synchrony, still do not allow reaching absolute stability: one (relatively static) stage of development is changing into the dynamic one. In this way, new trends appear. Variants of language elements on each synchronised section serve as a kind of indicators of changes taking place against the background of stable, unchanged components of the system" (Kostiv, 2010, p. 404). Since the question of the actual degree of changes in language, their quantitative and qualitative indicator of the particular period of development of the literary and written language, their influence on the formation of a certain language continuum constitute considerable lacunae in the studies of the history of the Ukrainian language, the method of quantitative calculations is of particular importance for determination of them. The totality of different language features in the medieval written monuments of northern and south-western areas and their place in the formation of the northern and south-western variants of the old Ukrainian language, separation of territorial-linguistic units in different periods will help you efficiently display linguo-geographical and descriptive research methods.

\section{The principle of synergetics}

Changes in the public mind, progress of the methodology as science generate new approaches and principles of linguistic research, in the sphere of linguistics "...the principles of the synergetics are increasingly penetrating, they postulate a focus on a language as a synergetic super-system, non-linear, unbalanced, determined from the inside and outside, which is in the state of transition from chaos to order and further - to a new order through the interaction of the destructive tendencies and parameters of organising this super-system" (Selivanova, 2009, p. 212). In the context of the theory of synergetics, the language facts are analysed in the mutual determinacy of different super-systems - infinite being, culture, and ethno-consciousness, worldview, society, etc. Holubovska (2013), stating the methodological crisis in linguistic science, which is evident in the eclecticism of a variety of methodological approaches, methodological uncertainty, reductionism, the scientific thinking inertia, suggests that it is a synergistic approach will be the basis for the formation of a fundamentally new vision and understanding of the World by a Person (p. 72-73).

For example, when identifying and analysing certain dialectal features of variable elements in the liturgical and business monuments the synergistics of a live national speech is essential, and then the native language of the author, a copyist of texts, because, by the observations of the linguists ".. for each individual only native language can fully reveal its depth, opportunities, it becomes the most convenient, most perfect, the sweetest "tool" for cognitive activities to the heart" (Batsevych, 2009, p. 95). Creating a unique to each person spiritual unity with the world, the native people's word forms the dialect space, the system of Ukrainian dialect continuum, a kind of a language plane of the nation's existence. In connection with this nature of the language development, the studied written monuments of the Ukrainian language are means of reproducing inter-lingual and inter-dialect contact, demographic shifts and migration processes, which, for example, were clearly illustrated by Moisiienko (2003) at describing the language of the Kholmshchyna "Articles to Kosopudskyi Brotherhood" of the second half of the XVII century: despite the fact that the document is of a church orientation, it is characterised by consistent southern-Ukrainian dialect features, shows a significant Polish influence and by a combination of linguistic peculiarities it allows us to draw a conclusion on the origin of the clerk - from the southern Kholmshchyna or the northwest of the Dniester region.

The system of methodological principles for the comprehensive study of linguistic variation in the diachrony is ramified, which is due to the specifics of the linguistic material, the growing interest of the scientists in the problems of the historical study of the language, the active development of theoretical and methodological foundations of linguistics.

\section{Conclusions}

Consequently, we conducted an analysis of the system of methodological principles of the comprehensive study of linguistic variation in diachrony on the basis of the studying the texts of the Ukrainian written artifacts of the XIV - XV centuries.

First of all, we specified the content of the "scientific principles" concept, which are global statements having strategic importance as tools for scientific research at its initial, intermediate and final stages.

Having described the system of methodological principles of diachronic study of linguistic variation from the perspective of the Ukrainian written artifacts of the late Middle Ages, we state: the methodology of diachronic study of variable language phenomena is based on the principles of a scientific and objective approach to coverage of the variation of the literary language in concrete historical conditions, on the basis 
of historicism, systemacity, anthropocentrism, dynamism and synergetics. The obtained results of our scientific study specify the methods of differentiation of language variants; enlarge the methodological principles of scientific cognition of language in diachrony.

The results of the study are also crucial in that they open up new approaches to the territorial segmentation of the Ukrainian language of the XIV - XV centuries, in particular, the identification of its varieties (North Ukrainian, South-western Ukrainian, etc.). The practical value of the work is determined by the possibility of using scientific generalisations for writing fundamental works on the history of the Ukrainian language, historical grammar and dialectology, as well as for typological studies of the comparative grammar of Slavic languages.

The described methodological aspects of the study of linguistic variation should be used to create training courses in general linguistics, historical grammar of the Ukrainian language, the history of the Ukrainian literary language and historical dialectology, to develop special courses in "Language variation in diachrony", "Principles and methods of linguistic analysis of linguistic variation", "Formation of standards of the Ukrainian language" for students of philological faculties of universities.

Perspectives of theoretical and methodological scientific schools in regards to language variations are seen in the study of variant language units at different levels of language structure in written artifacts of different periods of language functioning, in the separation of functional variants of literary and written language on the basis of the obtained linguistic facts of other historical periods.

The written technique of analysis of written monuments allows further systematic study of variant phonetic, morphological, lexical and other linguistic elements, helps to find out the causes of linguistic swings, to establish tulle, dialects, foreign language influences in the emergence of phonetic, morphological, lexical variants, helps to identify the place of linguistic parallelism in the formation of language as a multifunctional system.

\section{References:}

Andersen, H. (1969). A Study in Diachronic Morphophonemics: The Ukrainian Prefixes. Language, 45(4), 807-830. https://doi.org/10.2307/412336

Batsevych, F. (2009). Dukhovna synerhetyka ridnoi movy [Spiritual Synergetics of the Native Language]. Kyiv, Ukraine: Vydavnychyi tsentr „Akademiia”.

Buzuk, P. (1931). Z istorii dialektolohii ukrainskoi movy. Hovirka Lutskoi Yevanhelii XIV v. [From the History of the Dialectology of the Ukrainian Language. Sub-dialect of Lutsk Gospel of XIV century]. Zbirnyk Komisii dlia doslidzhennia istorii ukrainskoi movy, 1, 113-135. Retrieved 10 December 2018 from http://elib.nlu.org.ua/view.html?\&id=10536

Farion, I. (2015). Suspilnyi status staroukrainskoi (ruskoi) movy u XIV - XVII stolittiakh: movna svidomist, movna diisnist, movna perspektyva: monohrafiia [Public Status of the Old-Ukrainian (Rus) language in the XIV - XVII centuries: Language Consciousness, Language Reality, Language Perspective: a monograph]. Lviv, Ukraine: Vyd-vo Lvivskoi politekhniky.

Hlushchenko, V. A. (2010). Linhvistychnyi metod i yoho struktura [Linguistic Method and its Structure]. Movoznavstvo, 6, 32-44. Retrieved 12 December 2018 from https://movoznavstvo.org.ua/vsi-nomera-zhurnalu/47-2010-6-listopad-gruden.html

Holubovska, I. (2012). Problema metodolohii linhvistychnykh doslidzhen u mizhdystsyplinarnomu vysvitlenni [The Problem of Linguistic Research Methodology in Interdisciplinary Coverage]. Studia linguistica, 6 (1), 67-75. Retrieved 14 December 2018 from http://studia-linguistica.knu.ua/problema-metodologii-lingvistichnih-doslidzhen-u-mizhdisciplinarnomu-visvitlenni/

Hryshchenko, A. P. [Ed.] (2002). Suchasna ukrainska literaturna mova: pidruchnyk [Modern Ukrainian Literary Language: a textbook]. Kyiv, Ukraine: Vyshcha shkola.

Kostiv, O. (2010). Spivvidnoshennia dynamiky ta statyky v movi [The Balance of Dynamics and Statics in the Language]. Visnyk Lvivskoho universytetu. Seriia filolohichna, 50, 404-407. Retrieved 12 December 2018 from http://publications.lnu.edu.ua/bulletins/index.php/philology/article/view/3984

Kubrjakova,E. S. (1995). Jevoljucija lingvisticheskih idej v konce XX veka (opyt paradigmal'nogo analiza) [Linguistic Ideas Evolution at the End of the Twentieth Century (Paradigm Analysis Experience)]. In Stepanov, Yu. S. (Ed.), Jazyk i nauka konca XX veka (pp. 239-320). Moskva, Rossija: Institut jazykoznanija RAN.

Kuraszkiewicz, W. (1934). Gramoty halicko-wotyńskie XIV-XV wieku. Studium językowe [Galician-Volhynian Chronicles of the 14-15th centuries. Language study]. Kraków: Druk. Uniwersytetu Jagiellońskiego.

Melnychuk, O. S. (2000). Metodolohiia u movoznavstvi [Methodology in Linguistics]. In Rusanivskyi, V. M., Taranenko, O. O., Ziabliuk, M. P. (Eds.), Ukrainska mova. Entsyklopediia (pp. 311-312). Kyiv, Ukraine: Vydavnytstvo „Ukrainska entsyklopediia" imeni M. P. Bazhana.

Moisiienko, V. (2016). Istorychna dialektolohiia ukrainskoi movy. Pivnichne (poliske) narichchia [Historical Dialectology of the Ukrainian Language. Northern (Polissia) Dialect]. Kyiv, Ukraine: Vydavnychyi tsentr „Akademiia”.

Moisiienko, V. (2003). Pamiatka ukrainskoi movy z pivdnia Kholmshchyny [The Monument of the Ukrainian language from the south of the Kholmshchyna]. Slavia Orientalis, LII/ 4, 553-562.

Nimchuk, V. V. (1981). Peredmova [Introduction]. In Nimchuk, V. V. (Ed.), Dilova mova Volyni i Naddniprianshchyny XVII st. [Business language of Volyn and Naddnieper of the XVII century] (pp. 5-23). Kyiv, Ukraine: Naukova dumka.

Ohiienko, I. (1930). Ukrainska literaturna mova XVI stolittia i Krekhivskyi „,Apostol” 1560 roku [Ukrainian literary language of the XVI century: Krekhiv Apostle of the year 1560]. Varshava: Drukarnia synodalna.

Pankevych, I. (1958). Zakarpatskyi dialektnyi variant ukrainskoi literaturnoi movy XVII - XVIII vv [Transcarpathian dialect variant of the Ukrainian literary language of the XVII - XVIII centuries]. Slavia, XXVII, 2, 171-181. 
Pivtorak, H. (2015). Deiaki metodolohichni problemy doslidzhennia istorii ukrainskoi movy na suchasnomu etapi [Some Methodological Problems of Studying the History of the Ukrainian Language at the Present Stage]. In Moisiienko, V. (Ed.), Ukrainskyi hlotohenez [Ukrainian Glottogenesis] (pp. 5-18). Zhytomyr, Ukraine: Polissia.

Ruszkowski, M. (2014). Typy wariantywności w języku polskim [Variation Types in the Polish Language]. Respectus Philologicus, 25 (30), 53-62. https://doi.org/10.15388/RESPECTUS.2014.25.30.3

Selivanova, O. O. (2009). Lingvometodologiya - naukova paradygma - epistema [Linguistic methodology - scientific paradigm episteme]. Naukovyj visnyk Cherniveczkogo universytetu. Slov'yanska filologiya, 475-477, 208-214. Retrieved 12 December 2018 from http://www.nbuv.gov.ua/j-pdf/Nvchnusf_2009_475-477_38.pdf

Stang, Chr. (1935). Die westrussische Kanzleisprache des Grossfürstentums Litauen. [Western Russian law language of the Grand Duchy of Lithuania]. Oslo: Jacob Dybwad.

Tarlanov, Z. K. (1995). Metody i principy lingvisticheskogo analiza [Methods and Principles of Linguistic Analysis]. Petrozavodsk, Russia: Izdatel'stvo Petrozavodskogo universiteta.

Tsaralunga, I. (2014). The variation features within the Vyzhva Register grammar system (written in the XVII century). Journal of Language and Literature, 5(4), 225-229. Retrieved 10 December 2018 from http://elar.khnu.km.ua/jspui/handle/123456789/4573

Tsaralunga, I. (2011). Do pytannia movnoi osnovy ukrainsko-biloruskykh pysemnykh pamiatok XIV - XVII st. [On the Issue of the Linguistic Basis of the Ukrainian-Belarussian Written Monuments of the XIV - XVII centuries]. Problemy slovianoznavstva, 60, 202-206. Retrieved 12 December, 2018 from http://publications.lnu.edu.ua/collections/index.php/slavonic/article/view/2201

Tsaralunga, I. (2018). Metodolohichni aspekty doslidzhennia movnoi variatyvnosti v diakhronii [Methodological aspects of the study of linguistic variability in diachrony]. Visnyk Lvivskoho universytetu. Seriia filolohichna, 68, 100-111. Retrieved 10 December 2018 from http://publications.lnu.edu.ua/bulletins/index.php/philology/article/view/8917/8892

Tsaralunga, I. (2016). Refleksy praslovianskoho *ě u movi ukrainskykh hramot XIV st. [Reflexes of Proto-Slavic *ě in the Language of the Ukrainian Letters of XIV century]. Slavia Orientalis, LXV/1, 161-172. Retrieved 10 December 2018 from http://journals.pan.pl/dlibra/publication/96793/edition/83541/content

Tsaralunga, I. (2017). Variatyvnist u staroukrainskii literaturno-pysemnii movi XIV - XV st.: monohrafiia [Variation in the Old Ukrainian Literary Written Language of the XVI - XVI centuries: a monograph]. Khmelnytskyi, Ukraine: FOP Honta A. S.

Received: January 17, 2019

Accepted: November 15, 2019 